УДК: 578: 656.835.91: 737.23

\title{
В.Ю. Барштейн
}

Государственное учреждение «Институт пищевой биотехнологии и геномики НАН Украины», ул. Осиповского, 2а, Киев, 04123,Украина, тел.: +38(044) 46272 59, e-mail: ihtbar@rambler.ru

\section{ПЕРВЫЕ ШАГИ ВИРУСОЛОГИИ В ПАМЯТНИКАХ ФИЛАТЕЛИИ И НУМИЗМАТИКИ}

\begin{abstract}
Статья посвящена первым шагам вирусологии - открытию возбудителей: мозаиной болезни табака, ящура, желтой лихорадки, бешенства, натуральной оспь, полиомиелита, саркомь Рауса. Рассказ проиллюстрирован произведениями филателии и нумизматики разных стран: СССР, ФРГ, Нидерландов, США, Румьнии, Португалии, Гвинейской Республики, Украины и ООН.
\end{abstract}

Ключевые слова: история вирусологии, филателистическая продукция, памятная медаль.

В статье [1], рассказавшей о некоторых событиях из истории микробиологии и проиллюстрированной произведениями медальерного искусства, был и короткий рассказ о выдающемся русском физиологе растений и микробиологе Дмитрии Иосифовиче Ивановском, который в 1892 г. впервые открыл существование вируса (как нового типа возбудителя болезней), называемого им то «фильтрующимися» бактериями, то микроорганизмами.

К столетию со дня рождения Д.И. Ивановского в 1964 г. почта СССР выпустила марку (достоинство - 4 коп., цвет - серо-коричневая, сине-серая, художник - С. Соколов). На марке (рис. 1) изображен портрет ученого и его факсимиле. Слева, вертикально надпись: «ПЕРВООТҚРЫВАТЕЛЬ ВИРУСОВ». В левом нижнем углу - колба с бактериальным фильтром. Фильтр больше напоминает воронку Бюхнера с впаянной пластинкой из мелкопористого стекла, хотя должен быть изображен фильтр Шамберлана. В правом нижнем углу - годы жизни Ивановского: «1864-1920».

Тот же метод фильтрации, которым Ивановский открыл возбудитель мозаичной болезни табака, использовали немецкие бактериологи и вирусологи: один из основоположников медицинской микробиологии, Фридрих Август Иоганн Леффлер (нем. Friedrich August Johannes Loeffler, 1852-1915) и Пауль Фрош (нем. Paul Frosch, 1860-1928), когда установили в 1898 г. фильтруемость возбудителя ящура (Aphtae epizooticae), страшной болезни животных. Возбудитель ящура относится к семейству Picornaviridae и является одним из наиболее мелких РНК-содержащих вирусов.

(C) В.Ю. Барштейн, 2011 


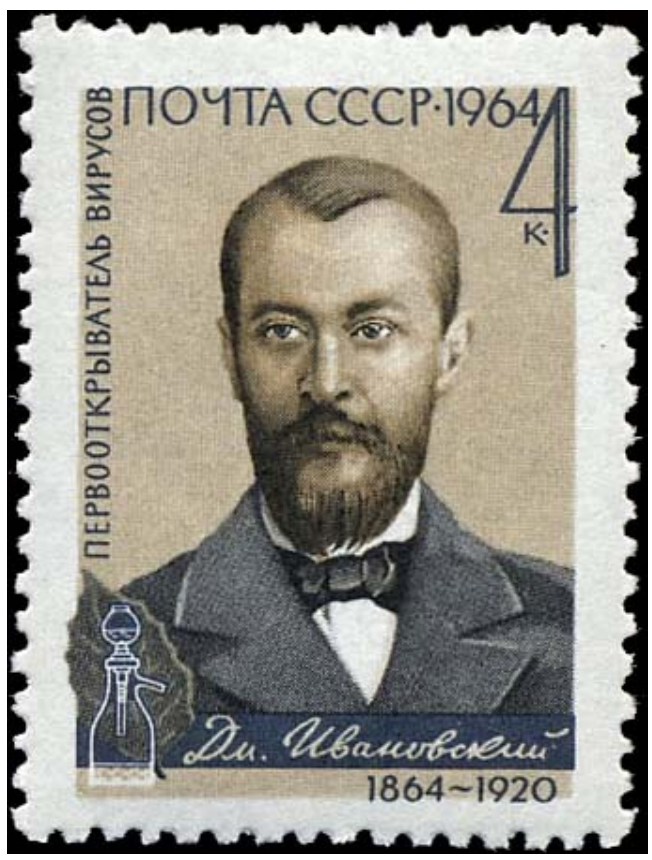

Рис. 1. Д.И. Ивановский. Почтовая марка (СССР)

Fig. 1. D.I. Ivanovsky. Postage stamp (USSR)

Фридрих Леффлер открыл также, совместно с соавторами, возбудителей: дифтерии (Corynebacterium diphtheriae), лошадиного сапа (Pseudomonas mallei), мышиного тифа (Salmonella typhimurium) и т.д. [2].

Портрет ученого украшает немецкую марку (рис. 2) достоинством в 85 центов, выпущенную в 2010 г. в ознаменование 100-летия Института им. Фридриха Леффлера (нем. Friedrich-Loeffler-Institut), национального исследовательского ветеринарного центра Германии, основанного Леффлером и получившим его имя в 1952 г. Упомянутый портрет расположен в левой стороне марки, справа - микроскоп на фоне изображения вируса, в центре - модель вируса (в разрезе).

В 1898 г. опыты Д.И. Ивановского воспроизвел нидерландский микробиолог и ботаник, член-корреспондент и почетный член Российской академии наук Мартин Виллем Бейеринк (нидерл. Martinus Willem Beijerinck, 1851-1931). Он назвал микроорганизмы, открытые Ивановским «фильтрующимися вирусами». Со временем данную группу микроорганизмов стали называть вирусами.

Заслуги Бейеринка, которого некоторые считают основателем вирусологии, перед микробиологической наукой трудно переоценить. Он стал, среди прочего, первооткрывателем симбиотических азотфиксаторов (1888), свободноживущих аэробных азотфиксаторов (1901), сульфатредуцирующих бактерий, наряду с С.Н. Виноградским [1], стал одним из основателей почвенной и экологической микробиологии [2]. 


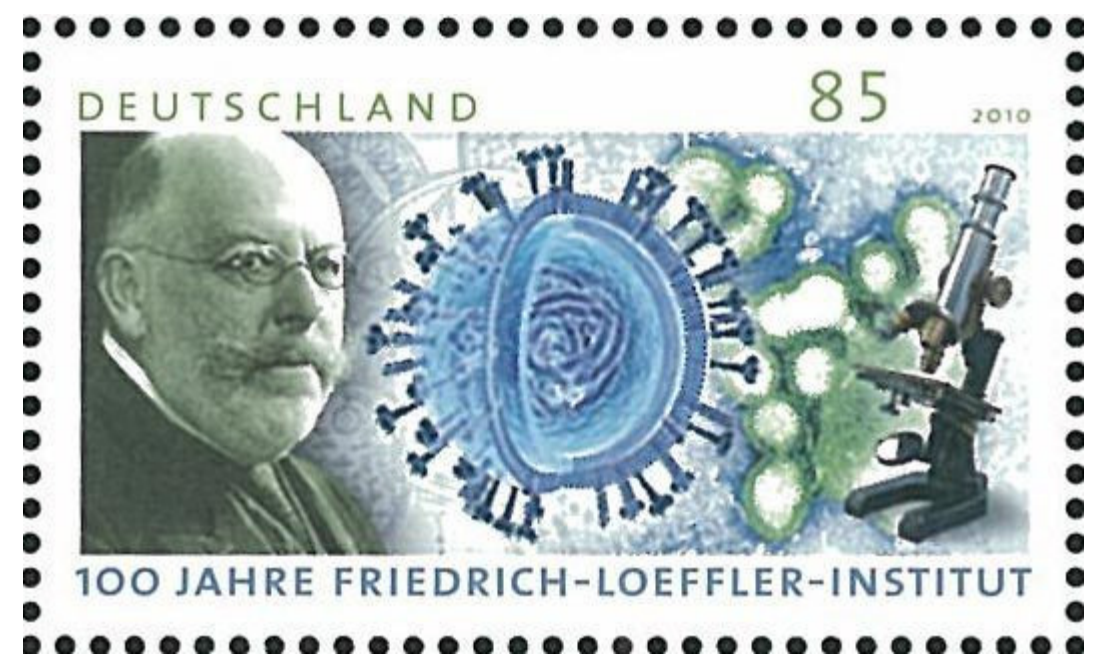

Рис. 2. Фридрих Леффлер. Почтовая марка (ФРГ)

Fig. 2. Friedrich Loeffler. Postage stamp (Germany)

Нидерландская королевская академия наук (нидерл. Koninklijke Nederlandse Akademie van Wetenschappen, KNAW) учредила в 1965 г. премию имени Мартина Виллема Бейеринка по вирусологии, которая вручается каждые два года за выдающиеся достижения в этой области знаний [3]. Помимо денежного вознаграждения в 35000 евро награжденный получает золотую медаль, в центре аверса которой расположен рельефный, погрудный, профильный, повернутый вправо портрет Бейеринка (рис. 3). По краю медального поля, по кругу надпись на латыни: «MARTINUS WILLEM BEIJERINCK EGREGIUS VIROLOGIЖ CONDITOR» (МАРТИН ВИЛЛЕМ БЕЙЕРИНК БЛИСТАТЕЛЬНЫЙ ОСНОВОПОЛОЖНИК ВИРУСОЛОГИИ).

Утонченный растительный орнамент по краю медального поля реверса (рис. 4) оставляет центральную часть его для посвящения награжденному.

Увлекательные страницы истории борьбы с желтой лихорадкой [4] можно было бы проиллюстрировать дюжиной прекрасных памятных медалей. Вирусная природа желтой лихорадки, первого обнаруженного вирусного заболевания человека, была доказана Уолтером Ридом (англ. Walter Reed, 1851-1902) и Джеймсом Кэроллом (англ. James Carroll, 1854-1907) в 1901-1902 гг., после того, как при подкожном введении трем добровольцам профильтрованной сыворотки больных у двух из них возникло заболевание. Заболевание вызывается вирусом из семейства Flaviviridae.

Американская медаль (44 мм, бронза, Medallic Art Co. N.Y., США, 1971), посвященная Уолтеру Риду, создана A. Belskie (в серии медалей в честь выдающихся деятелей медицины всех веков и народов). 


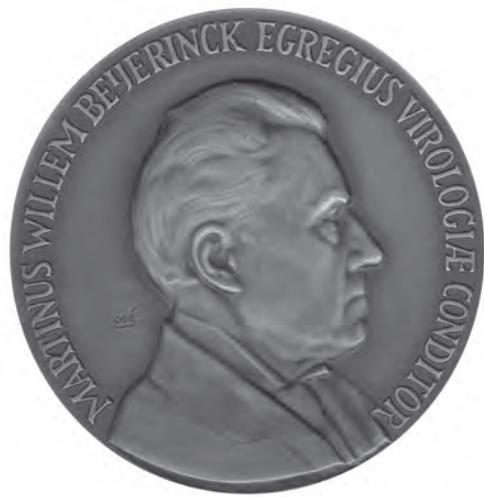

Рис. 3. Мартин Виллем Бейеринк. Медаль, аверс (Нидерланды)

Fig. 3. Martinus Willem Beijerinck. Medal, obverse (Netherlands)

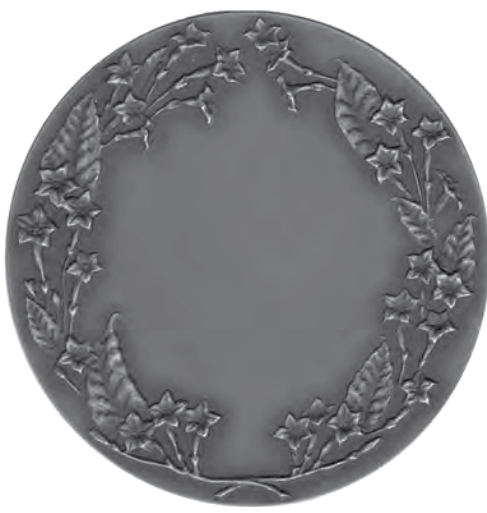

Рис. 4. Мартин Виллем Бейеринк. Медаль, реверс (Нидерланды)

Fig. 4. Martinus Willem Beijerinck. Medal, reverse (Netherlands)

Высокорельефный, полупогрудный, профильный, повернутый на $\neq$ вправо портрет врача на фоне канала, растущих на берегу пальм, занимает центральную часть аверса медали (рис. 5). Справа от портрета - рельефное изображение москита Aedes aegypti, переносчика желтой лихорадки, на фоне вирусной частицы. Выше - горизонтальная надпись в две строки, годы жизни Уолтера Рида: «1851 / 1902». По краю медального поля, по кругу, надпись на английском языке, сверху: «WALTER REED», снизу: «CONQUEST OF YELLOW FEVER» (ПОБЕДА НАД ЖЕЛТОЙ ЛИХОРАДКОЙ).

Реверс медали (рис. 6) занимает высокорельефная композиция: двое полуобнаженных землекопов, продираясь сквозь джунгли, копают канал. Над изображением, по краю медального поля, по кругу сверху и справа надпись на английском языке: «PANAMA CANAL» (ПАНАМСКИЙ КАНАЛ).

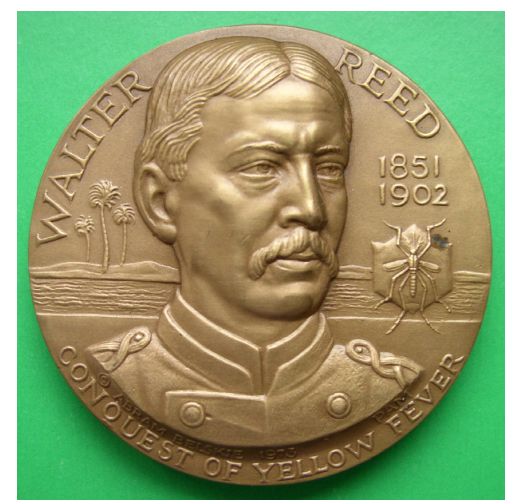

Рис. 5. У. Рид. Медаль, аверс (США) Fig. 5. W. Reed. Medal, obverse (USA)

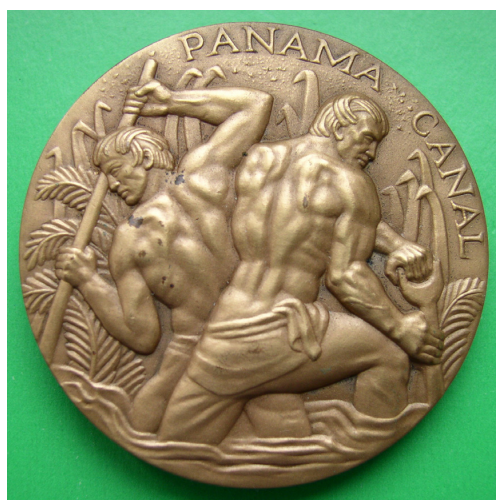

Рис. 6. У. Рид. Медаль, реверс (США) Fig. 6. W. Reed. Medal, reverse (USA) 
Борьбу с бешенством Луи Пастер [1] начал еще до открытия возбудителя этого вирусного заболевания.

Румынский врач, биолог и один из первых микробиологов Виктор Бабеш (рум. Victor Babes, 1854-1926) и итальянский патолог и микробиолог Адельчи Негри (итал. Adelchi Negri, 1876-1912) обнаружили (1898-1903) в нейронах головного мозга заражённых бешенством внутриклеточные включения (тельца Бабеша-Негри) [5]. Вирусную природу бешенства доказал в 1903 г. французский врач Поль Ремленже (фр. Paul Remlinger, 1871-1964).

Бабеш внес весомый вклад в изучение бешенства, лепры, дифтерии, туберкулеза и других инфекционных заболеваний. Он описал в 1888 г. Babesia - род протозоа отряда пироплазмид класса споровиков, возбудителя Техасской лихорадки крупного рогатого скота.

Портрет Виктора Бабеша, рельефный, головной, профильный, повернутый влево, поместил скульптор I. Jalea в центр аверса румынской

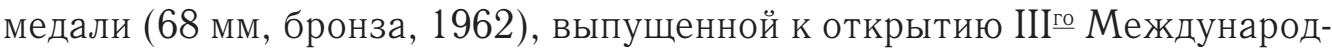
ного конгресса по инфекционной патологии (рис. 7). По краю медального поля, по кругу, слева, сверху и справа надпись: «PROFESORUL D VICTOR BAВЕSุ» (ПРОФЕССОР Д-Р ВИКТОР БАБЕШ), снизу - годЫ жизни ученого: «1854-1926».

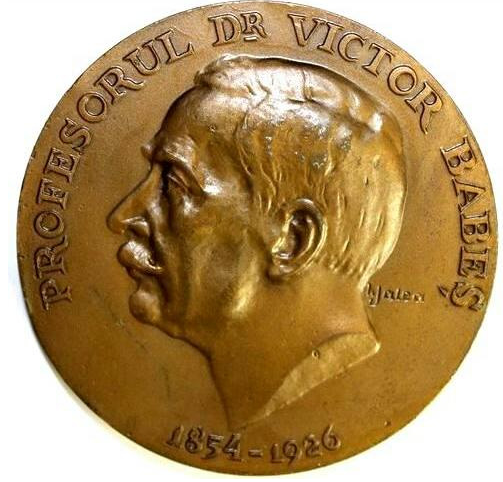

Рис. 7. В. Бабеш. Медаль, аверс (Румыния)

Fig. 7. V. Babeș. Medal, obverse (Romania)

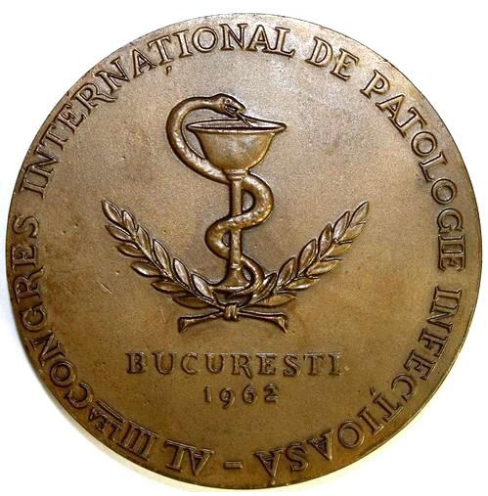

Рис. 8. В. Бабеш. Медаль, реверс (Румыния)

Fig. 8. V. Babeș. Medal, reverse (Romania)

Лаконичным и традиционным сделал скульптор реверс медали (рис. 8). В центре - медицинская эмблема (чаша со змеёй), под которой - скрещенные лавровые ветки. Ниже - горизонтальная надпись в две строки: «BUCURESTI / 1968» (БУХАРECT / 1962). По краю медального поля, по кругу надпись: «AL IIILEA CONGRES INTERNAȚIONAL DE

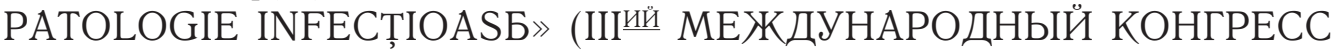


ПО ИНФЕКЦИОННОЙ ПАТОЛОГИИ). Все надПиси на медали - на румынском языке.

Тысячи и тысячи людей погибли на протяжении столетий от натуральной оспы (лат. Variola, Variola vera) или, как её ещё называли ранее, чёрной оспы - высококонтагиозной вирусной инфекции.

Несмотря на то, что английский врач Эдвард Дженнер (англ. Edward Jenner, 1749-1823) разработал вакцину против оспы (вообще - первую вакцину) и 14 мая 1796 г. впервые ввел восьмилетнему мальчику Джеймсу Фипсу неопасный вирус коровьей оспы, возбудитель этого страшного заболевания был открыт только в 1906 г. немецким бактериологом Энрике Пашеном (нем. Enrique Paschen, 1860-1936). Пашен - автор многочисленных работ по натуральной оспе и оспенной вакцинации.

Искоренению натуральной оспы, в осуществление которой внесли свой вклад и Энрике Пашен, и, особенно, Эдвард Дженнер, посвящены две марки (рис. 9, 10), выпущенные 31.03.1978 г. почтовой администрацией Организации Объединённых Наций для офиса ООН в Женеве (в швейцарских франках $-0,8$ и 1,1).

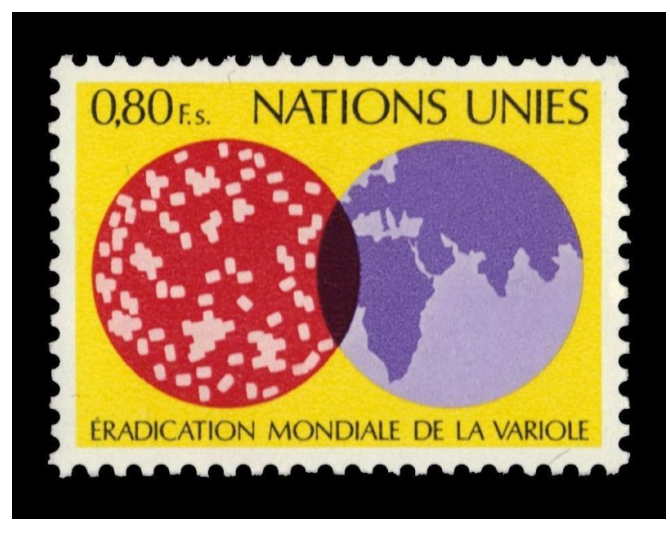

Рис. 9. Искоренение натуральной оспы, Почтовая марка $(\mathrm{OOH})$

Fig. 9. Eradication of Smallpox. Postage stamp (UN)

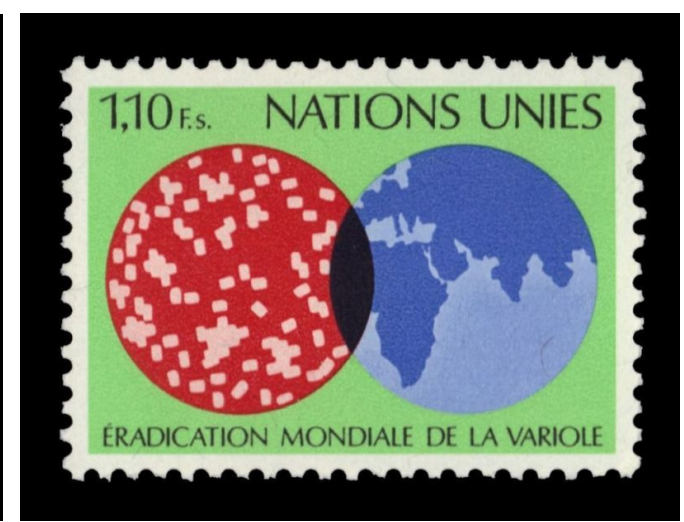

Рис. 10. Искоренение натуральной оспы. Почтовая марка $(\mathrm{OOH})$

Fig. 10. Eradication of Smallpox. Postage stamp (UN)

На марках на желтом (рис. 9) и зеленом (рис. 10) фоне изображены как бы два полушария. Слева - изображение восточного полушария: Африка, часть Европы и часть Азии, континенты, наиболее страдавшие от смертельной болезни. Справа, вместо континентов, возбудитель натуральной оспы.

1908-1909 гг. ознаменовались выделением вируса полиомиелита детского спинномозгового паралича, острого высококонтагиозного инфекционного заболевания. Методом заражения обезьян растертым мозгом умершего от полиомиелита ребенка это удалось сделать австрийцам: 
выдающемуся врачу, химику, иммунологу и инфекционисту Карлу Ландштейнеру (нем. Karl Landsteiner, 1868-1943) и врачу Эрвину Попперу (нем. Erwin Popper, 1879-1955).

Почтовая продукция Австрии, Румынии, бывшей ГДР, банкнота Австрии номиналом 1000 австрийских шиллингов (введена в обращение 20 октября 1997), множество памятных медалей посвящены Карлу Ландштейнеру. Связано это не с вышеупомянутым открытием, а с открытием групп крови человека, за которое Ландштайнер был удостоен Нобелевской премии по физиологии и медицине (1930).

Именно этому событию посвящена медаль (80 мм, бронза, Монетный двор Португалии, последняя треть XX века) которую создал известный португальский скульптор Cabral Antunes.

Центральную часть медального поля аверса (рис. 11) медали занимает рельефный, погрудный, почти анфас портрет ученого. Слева и сверху, по краю медального поля, по кругу надпись: «KARL LANDSTEINER» (КАРЛ ЛАНДШТАЙНЕР). Справа от портрета, горизонтально, в две строки - годы рождения и смерти ученого: «1868/1943».

В верхней части реверса (рис. 12), по краю медального поля, по кругу надпись: «РRЙМIO NOBEL DA MEDICINA» (НОБЕЛЕВСКАЯ ПРЕМИЯ ПО МЕДИЦИНЕ). Ниже, горизонтально - год присуждения премии: «1930». В нижней части медального поля реверса - надпись на португальском языке в три строки: «PELA DESCOBERTA DOS GRUPOS SANGUINEOS DA ЕSРЙСІЕ НUМАNA» (ЗА ОТКРЫТИЕ ГРУПП КРОВИ ЧЕЛОВЕКА). В центральной части реверса, на пластине, приподнятой над поверхностью реверса, таблица, иллюстрирующая открытие Ландштайнера.

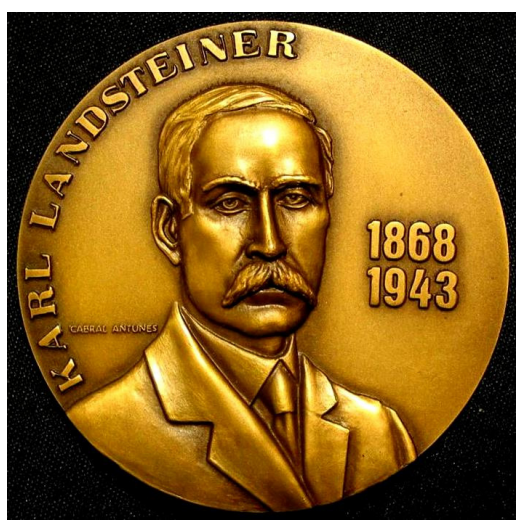

Рис. 11. Карл Ландштейнер. Медаль, аверс (Португалия)

Fig. 11. Karl Landsteiner. Medal, obverse (Portugal)

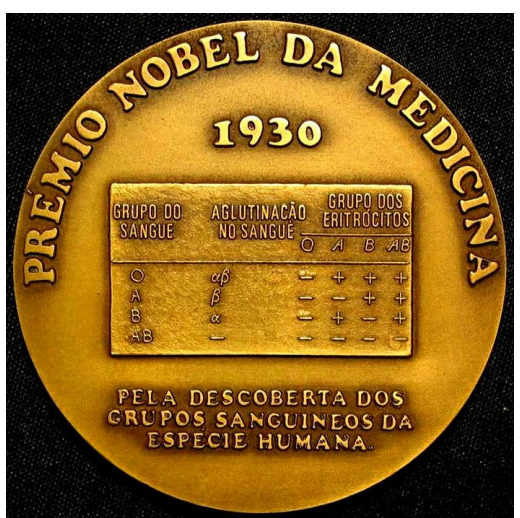

Рис. 12. Карл Ландштейнер. Медаль, реверс (Португалия)

Fig. 12. Karl Landsteiner. Medal, reverse (Portugal) 
В мае 2005 г. 58-я сессия Всемирной организации здравоохранения в Женеве приняла решение 14 июня (день рождения Карла Ланштейнера), ежегодно проводить Всемирный день донора крови.

55 лет пришлось ждать Нобелевской премии по физиологии и медицине (1966) «за открытие онкогенных вирусов» американскому патологу Фрэнсису Пейтону Раусу ( англ. Francis Peyton Rous, 1879-1970). Payc еще в 1911 г. доказал вирусную природу рака - саркомы Рауса.

В 2008 г. почтовое ведомство Гвинейской Республики (фр. Rŭpublique de Guinüe) - государства в Западной Африке, выпустило почтовый блок, посвященный Нобелевским лауреатам по физиологии и медицине разных лет. Блок состоит из 6 марок (рис. 13). На верхней правой марке изображен Фрэнсис Пейтон Раус в молодые и зрелые годы. Кроме него, на марках изображены: итальянский врач и ученый (Нобелевская премия (НП) 1906 г.) Камилло Гольджи (итал. Camillo Golgi, 1843-1926), американский биолог (НП 1933 г.) Томас Хант Морган (англ. Thomas Hunt Morgan, 1866-1945), швейцарско-американский биохимик (НП 1992 г.) Эдмонд Фишер (англ. Edmond H. Fischer, род. 1920), шведский фармаколог (НП 2000 г.) Арвид Карлссон (швед. Arvid Carlsson, род. 1923), американский молекулярный генетик (НП 2006 г.) Эндрю Захари Файер (англ. Andrew Z. Fire, род. 1959). Еще четыре выдающихся ученых изображены на блоке вокруг марок: американский цитогенетик (НП 1983 г.) Барбара Мак-Клинток (англ. Barbara McClintock, 1902-1992), шотландский бактериолог (НП 1945 г.) Александр Флеминг (англ. Sir Alexander Fleming, 1881-1955), американский физик, биофизик и физиолог (НП 1961 г.) Дьёрдь фон Бекеши (венг. Bŭkŭsy Gyurrgy; нем. Georg von Bǔkŭsy, 1899-1972), британский молекулярный биолог, врач и нейробиолог (НП 1962 г.) Фрэнсис Крик (англ. Francis Crick, 1916-2004).

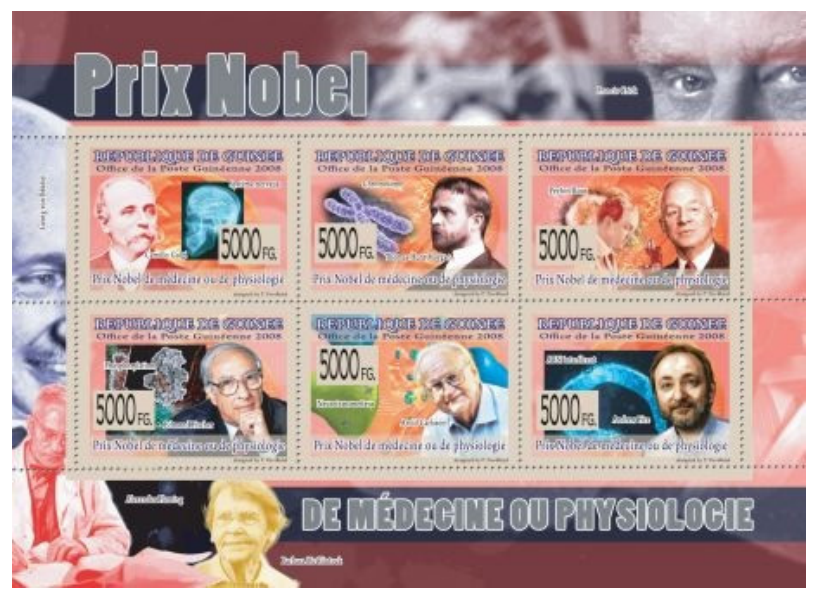

Рис. 13. Фрэнсис Пейтон Раус. Лауреаты Нобелевской премии по физиологии и медицине. Почтовый блок (Гвинейская Республика)

Fig. 13. Francis Peyton Rous. Nobel laureates in the field of physiology and medicine. Miniature sheet (Republic of Guinea) 
Наш рассказ был бы не полным без упоминания об еще одном ученом. В 2009 г. Укрпочта выпустила (к 150-летию со дня рождения) художественный маркированный конверт (ХMK), посвященный выдающемуся уроженцу Одессы, врачу, микробиологу и эпидемиологу, почётному члену АН СССР (1940), академику АМН СССР (1945), Лауреату Государственной премии СССР (1943) Николаю Фёдоровичу Гамалее (1859-1949). На конверте воспроизведен портрет ученого в молодые годы. Марки проштампованы специальным штемпелем, в центре которого - микроскоп (рис. 14).

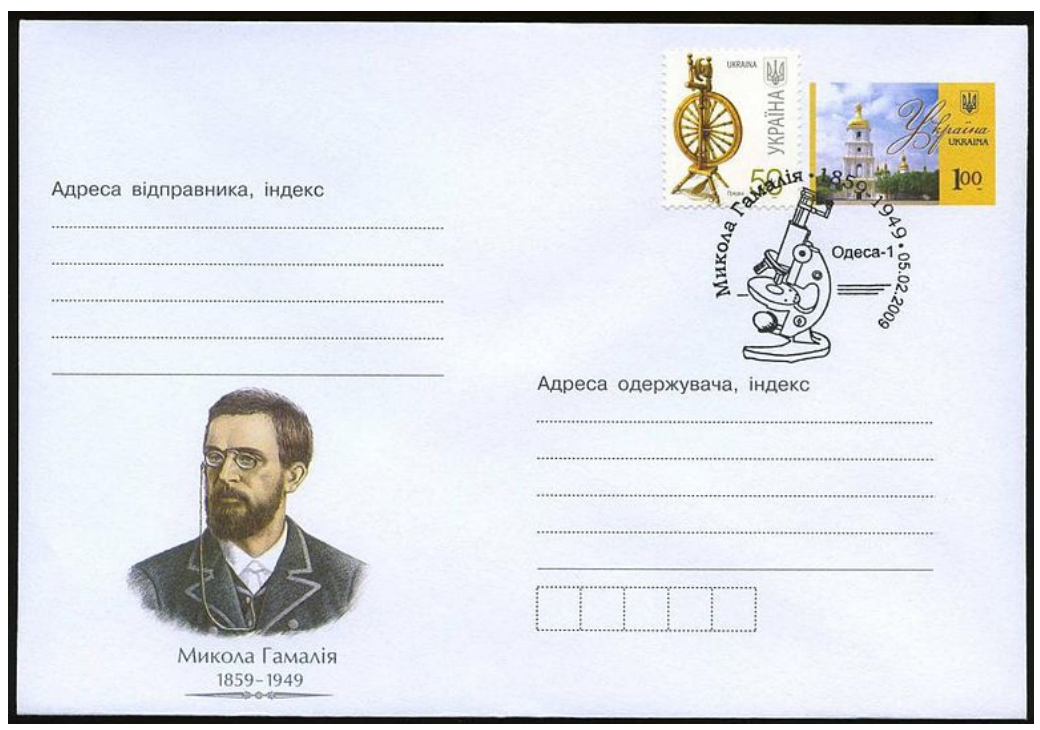

Рис. 14. Николай Фёдорович Гамалея. ХМК (Украина)

Fig. 14. Nikolay Fyodorovich Gamaleia. FDC (Ukraine)

Заслуги Гамалеи перед наукой настолько велики, что мы можем упомянуть только ряд из них. Совместно с И.И. Мечниковым и Я.Ю. Бардахом, при содействии Луи Пастера, Н.Ф. Гамалея участвовал в создании в Одессе в 1886 г. первой в России (и второй в мире) бактериологической станции и впервые в России осуществил вакцинацию людей против бешенства. За первые 3 года деятельности станции были сделаны прививки приблизительно 1500 человек, что в четыре раза снизило смертность от бешенства. С 1899 по 1908 г. Гамалея был директором основанного им Бактериологического института в Одессе. С 1912 по 1928 г. он руководил Петербургским (Петроградским) оспопрививательным институтом имени Дженнера. С 1930 по 1938 г. Н.Ф. Гамалея - научный руководитель Центрального института эпидемиологии и микробиологии в Москве (в настоящее время носит его имя). Деятельность ученого была посвящена борьбе с чумой в Одессе, холерой на юге России, профилактике тифов, холеры, чумы, оспы и других инфекционных заболеваний. 
Возвращаясь к теме нашей статьи, упомянем о большом теоретическом и практическом значении работ Н.Ф. Гамалеи по изучению фильтрующихся вирусов. Это и обнаружение того, что чума крупного рогатого скота вызывается ими, доказательство того, что возбудителем инфекционной анемии лошадей является вирус и т.д. Ещё в 1898 году Гамалея впервые наблюдал явление лизиса бактерий (сибиреязвенной палочки).

С образом Николая Федоровича Гамалеи связаны три медали (СССР). Две из них посвящены институту, в котором он работал в последние годы жизни и который носит его имя. Третья - выпущена в честь 125-летия со дня рождения ученого (бронза, 60 мм, Ленинградский монетный двор, 1987) [6].

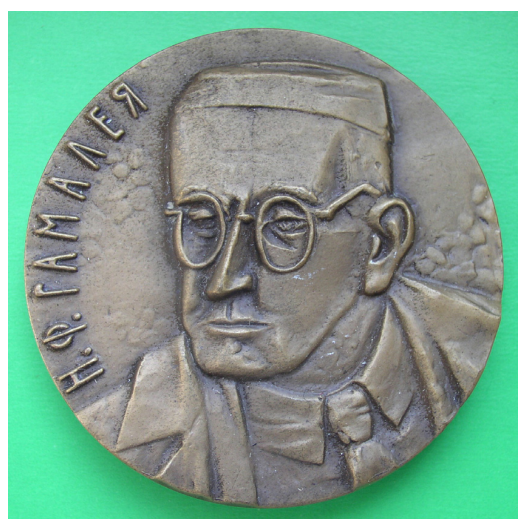

Рис. 15. Н.Ф. Гамалея. Медаль, аверс (СССР)

Fig. 15. N.F. Gamaleia. Medal, obverse (USSR)

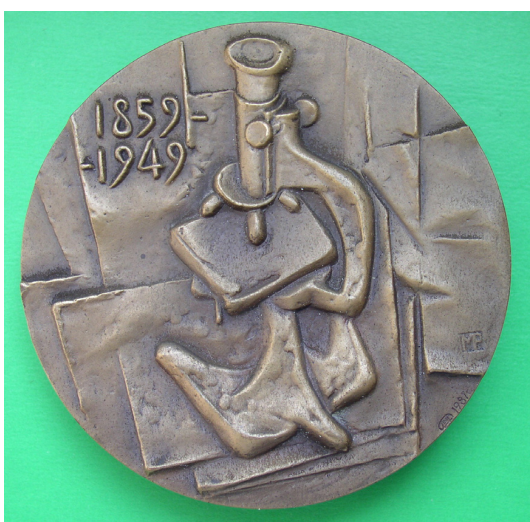

Рис. 16. Н.Ф. Гамалея. Медаль, реверс (СССР)

Fig. 16. N.F. Gamaleia.

Medal, reverse (USSR)

Оригинальный портрет ученого (каким он был в последние годы жизни) выполнен скульптором Марианной Романовской в несколько стилизованной манере, с обостренными линиями, которые подчеркивают остроту ума, деловитость, бескомпромиссность исследователя. Полупогрудный, профильный, повернутый на $\neq$ влево портрет ученого в очках и тюбетейке, которую он носил много лет, занимает почти все медальное поле аверса (рис. 15). Слева, по краю медального поля, по кругу надпись: «Н.Ф. ГАМАЛЕЯ».

В центре реверса (рис. 16) на фоне рукописей - изображение микроскопа, которым ученый пользовался для своих исследований и открытий. Слева сверху, горизонтально в две строки - годы его рождения и смерти: «1859-/-1949».

K сожалению, формат журнальной статьи позволил нам лишь упомянуть о первых шагах вирусологии - открытии ряда вирусов, о 
выдающихся ученых - авторах этих открытий. Почтовые марки, блоки, ХMK, памятные медали позволили нам проиллюстрировать этот рассказ. Такое использование памятников материальной культуры может послужить своеобразным пособием в изучении истории науки.

\section{ЛИТЕРАТУРА}

1. Барштейн В.Ю. Страницы истории микробиологии в медальерном искусстве [Текст] / В.Ю. Барштейн // Мікробіологія і біотехнологія.2011.- № 1(13) .- С. 86-94.

2. Шлегель Г.Г. История Микробиологии: Пер. с нем. Т.Г. Мирчинг [Текст] / Г.Г. Шлегель.- М.: Едиториал УРСС, 2002.- 304 с. ISBN 5-354-00010-6.

3. Beijerinck Virology Prize [Электронный ресурс]. - Режим доступа: http://www.knaw.nl/Pages/DEF/27/202.bGFuZz1FTkc.html

4. Де Крюи Поль. Охотники за микробами. Борьба за жизнь: Пер. с англ. И.П. Червонского [Текст] / Поль де Крюи.- М.: Наука, 1987.-432 с.

5. Сорокина T.С. История медицины: учебник для студ. высш. мед. учеб. заведений [Текст] / Т.С. Сорокина.- М.: Издательский центр «Академия», 2006.- 560 с. - ISBN 5-7695-3125-8.

6. Барштейн Ю.А. Медицина в медальєрному мистецтві [Текст] / Ю.А. Барштейн, В.Ю. Барштейн.- Тернопіль: Укрмедкнига, 2003.352 c.- ISBN 966-673-046-4.

\section{В.Ю. Барштейн}

Державна установа «Інститут харчової біотехнології та геноміки НАН України», вул. Осиповського, 2а, Київ, 04123, Україна, тел.: +38 (044) 46272 59, e-mail: ihtbar@rambler.ru

\section{ПЕРШІ КРОКИ ВІРУСОЛОГІЇ В ПАМ'ЯТКАХ ФІЛАТЕЛІЇ I НУМІЗМАТИКИ}

\section{Реферат}

Стаття присвячена першим крокам вірусології - відкриттю збудників: мозаїчної хвороби тютюну, ящура, жовтої лихоманки, сказу, натуральної віспи, поліомієліту, саркоми Рауса. Розповідь проілюстровано творами філателії і нумізматики різних країн: СРСР, Німеччини, США, Нідерландів, Румунії, Португалії, Гвінейської Республіки, України та ООН.

Ключові слова: історія вірусології, філателістична продукція, пам'ятна медаль. 


\section{V.Yu. Barshteyn}

Institute of Food Biotechnology and Genomics, NASU, 2a, Osipovskogo str., Kyiv, 04123, Ukraine, tel.: +38 (044) 46272 59, e-mail: ihtbar@rambler.ru

\section{FIRST STEPS OF VIROLOGY IN MONUMENTS OF PHILATELY AND NUMISMATICS}

\section{Summary}

The article is devoted to the reflection of the first steps of virology discovery of causative agents of: tobacco mosaic disease, foot-and-mouth disease, yellow fever, rabies, natural pox, poliomyelitis, Rous sarcoma. The story is illustrated with works of philately and numismatics of different countries: USSR, Germany, Netherlands, USA, Romania, Portugal, Republic of Guinea, Ukraine and UN.

Key words: history of virology, philately objects, art medal. 